\title{
POLA KOMUNIKASI ORANG TUA DENGAN REMAJA YANG MELAKUKAN PERNIKAHAN DINI SAAT PANDEMI DI KABUPATEN KEDIRI
}

\author{
Anisa Dwi Pramesti ${ }^{1}$, Dyva Claretta ${ }^{2}$ \\ Program Studi Ilmu Komunikasi Fakultas Ilmu Sosial dan Imu Politik \\ Universitas Pembangunan Nasional "Veteran" Jawa Timur \\ Jalan Raya Rungkut Madya, Surabaya, Jawa Timur \\ anisadwipramesti7@gmail.com dan claretta.dici@gmail.com
}

\begin{abstract}
ABSTRAK
Komunikasi tentu terjadi dalam setiap keluarga. Komunikasi keluarga dan komunikasi antar pribadi yang terjalin dengan baik akan mempengaruhi individu dalam menjalani kehidupan di lingkungan masyarakat. Bentuk pengasuhan orang tua kepada anak dapat dipengaruhi oleh bagaimana pola komunikasi yang terbentuk.. Pada masa pandemi yang berdampak pada semua bidang menjadikan sebuah permasalahan baru bagi masyarakat. Penelitian ini dilakukan karena adanya kenaikan pernikahan dini yang signifikan sebanyak 100 persen di Kabupaten Kediri ketika pandemi Covid 19. Tujuan dari penelitian ini yaitu untuk mengetahui pola komunikasi antara orang tua dengan remaja yang melakukan pernikahan dini saat pandemi di Kabupaten Kediri. Penelitian ini menggunakan metode kualitatif deskriptif. Teknik pengumpulan data menggunakan wawancara mendalam. Teori yang digunakan yaitu pola komunikasi menurut Braumrind dan juga teori atribusi. Hasil penelitian menunjukkan bahwa penerapan pola komunikasi authoritarian (otoriter) terjadi pada anak remaja yang melakukan pernikahan dini akibat perjodohan yang dilakukan oleh orang tuanya. Sedangkan penerapan pola komunikasi permissive (membebaskan) terjadi pada pernikahan dini yang dilakukan anak remaja yang disebabkan kehamilan diluar nikah akibat kurangnya pengawasan orang tua serta anak yang tidak melanjutkan pendidikan ke jenjang yang lebih tinggi sehingga memutuskan untuk melakukan pernikahan dini akibat keinginan dan keputusan dirinya sendiri.
\end{abstract}

Kata Kunci : Pola Komunikasi, Pernikahan Dini, Pandemi Covid 19 


\title{
PARENTS OF COMMUNICATION PATTERNS WITH ADOLESCENTS WHO WERE EARLY MARRIAGE DURING PANDEMIC IN KEDIRI DISTRICT
}

\begin{abstract}
Communication certainly occurs in every family. Family communication and interpersonal communication that are well established will affect individuals in living life in the community. The form of parenting for children can be influenced by how communication patterns are formed. During the pandemic, which has an impact on all fields, it creates a new problem for the community. This research was conducted because of a significant increase in early marriage by 100 percent in Kediri Regency during the Covid 19 pandemic. The purpose of this study was to determine the communication pattern between parents and teenagers who married early during the pandemic in Kediri Regency. This research uses descriptive qualitative method. Data collection techniques using in-depth interviews. The theory used is the communication pattern according to Braumrind and also the attribution theory. The results showed that the application of authoritarian communication patterns (authoritarian) occurred in adolescents who had early marriages due to arranged marriages carried out by their parents. While the application of permissive communication patterns (liberating) occurs in early marriages carried out by teenagers due to pregnancies outside of marriage due to lack of parental supervision and children who do not continue their education to a higher level so they decide to do early marriage due to their own desires and decisions.
\end{abstract}

Keywords: Communication Pattern, Early Marriage, Covid 19 Pandemic 
Jurnal Ilmu Komunikasi UHO : Jurnal Penelitian Kajian Ilmu Komunikasi dan Informasi.

Volume 7, No. 1, Januari 2022, hlm 92-106

\section{PENDAHULUAN}

Kehidupan manusia sebagai makhluk sosial tidak pernah terlepas dari komunikasi. Dengan adanya komunikasi, hubungan antar manusia dapat terjalin dengan baik. Lingkup terkecil manusia dalam melakukan komunikasi dengan lingkungan sosialnya yaitu keluarga. Keluarga adalah kelompok primer yang paling penting dalam masyarakat. Keluarga merupakan sebuah grup yang terbentuk dari perhubungan laki-laki dan perempuan, perhubungan yang sedikit banyak berlangsung lama untuk menciptakan dan membesarkan anak-anaknya. Oleh karena itu, keluarga dalam bentuk murni merupakan suatu kesatuan sosial yang terdiri dari suami dan istri yang berperan sebagai orang tua serta anak-anak (Ahmadi, 2002:239 dalam Kartini, 2017).

Dalam kehidupan keluarga terdapat komunikasi antar pribadi dan komunikasi keluarga yang terjadi. Menurut Agus M. Hardjana (2003) dalam Sari (2017) mengatakan bahwa komunikasi antar pribadi ialah interaksi yang terjadi secara tatap muka antara dua orang atau lebih, dimana para pelaku komunikasi dapat melakukan penyampaian pesan dan menerima pesan secara langsung, serta para pelaku komunikasi juga dapat secara langsung menanggapi pesan saat proses komunikasi terjadi. Sedangkan komunikasi keluarga merupakan proses interaksi yang terjadi antar anggota keluarga, serta sebagai media penyalur dalam membentuk dan mengembangkan nilai-nilai yang dibutuhkan sebagai pegangan hidup (Novianti et al., 2017).

Komunikasi keluarga dan komunikasi antar pribadi yang terjalin dengan baik akan mempengaruhi individu dalam menjalani kehidupan di lingkungan masyarakat. Bentuk pengasuhan orang tua kepada anak dapat dipengaruhi oleh bagaimana pola komunikasi yang terbentuk. Menurut Kartini (2017) pola komunikasi diartikan sebagai bentuk atau pola hubungan dua orang atau lebih dalam proses pengiriman dan penerimaan cara yang tepat dalam penyampaian pesan, sehingga pesan yang dimaksud dapat dipahami. Pola komunikasi yang terbentuk pada keluarga dengan baik diharapkan menjadikan cara pengasuhan anak yang baik pula.

Menurut Braumrind : (Yusuf, 2001:51 dalam Sholihah, 2021) terdapat tiga pola komunikasi yang terjadi antara orang tua dengan anak yaitu, Authoritarian (Otoriter) merupakan pola dimana sikap penerimaan (acceptance) orang tua rendah, namun kontrol tinggi, suka menghukum secara fisik, bersikap mengkomando, bersikap kaku (keras), cendrung emosional dan bersikap menolak. Permissive (Membebaskan) yakni pola yang sikap penerimaan (acceptance) orang tua tinggi, namun kontrolnya rendah, memberi 
Jurnal Ilmu Komunikasi UHO : Jurnal Penelitian Kajian Ilmu Komunikasi dan Informasi.

Volume 7, No. 1, Januari 2022, hlm 92-106

kebebasan kepada anak untuk menyatakan dorongan atau keinginan. Authoritative (Demokrasi) merupakan pola dimana penerimaan (acceptance) orang tua dan kontrol tinggi, bersikap responsif terhadap kebutuhan anak, mendorong anak-anak untuk menyatakan pendapat atau pertanyaan, memberi pendapat tentang perbuatan yang baik dan buruk. Cara orang tua mengasuh anak akan mempengaruhi bagaimana pola berpikir anak, karena cara berpikir seseorang akan terbentuk dari lingkungan terdekatnya seperti teman dan keluarga (Latif, 2019).

Dalam sebuah keluarga, apabila terjadi penyampaian pesan yang tidak sesuai dapat menimbulkan sebuah permasalahan atau dapat dikatakan dengan kegagalan dalam berkomunikasi (Saifuddin \& Fanny, 2015). Permasalahan pada keluarga dapat terjadi karena orang tua yang memiliki keinginan yang tidak sesuai dengan kehendak anak ataupun sebaliknya. Dengan adanya sebuah permasalahan, menjadikan kedekatan antar anggota keluarga seperti orang tua dan anak menjadi renggang. Anak yang memasuki usia remaja akan cenderung lebih senang melakukan komunikasi dan berkegiatan diluar rumah, tanpa perhatian orang tua. Dengan demikian peran orang tua sebagai pembimbing atau pengarah sangat penting bagi anak yang memasuki usia remaja sebagai cerminan dan tolok ukur untuk melakukan kehidupan di lingkungan masyarakat..

Masa remaja atau adolesens merupakan periode perkembangan selama dimana individu mengalami perubahan dari masa kanak-kanak menuju dewasa, biasanya terjadi antara usia 10 hingga 19 tahun menurut data dari WHO (World Health Organization). Istilah adolesens biasanya menunjukkan maturasi psikologis individu, ketika pubertas menunjukkan titik dimana reproduksi mungkin dapat terjadi (Debby et al., 2021). Pada titik dimana seorang anak yang beralih menuju masa dewasa, maka seseorang itu sedang mencari jati dirinya dengan melakukan berbagai kegiatan. Sehingga banyak anak remaja yang melakukan kegiatan yang tidak terarah apabila tidak dengan pengawasan dan bimbingan orang tuanya, seperti banyaknya kasus di Indonesia mengenai anak remaja yang melakukan pergaulan bebas akibat kurangnya perhatian orang tua.

Berdasarkan data yang disadur pada wartakotalive.com mengatakan bahwa hasil survei KPAI pada tahun 2007, dari 4.500 remaja Indonesia yang disurvei 97 persen di antaranya mengaku pernah menonton film porno. Sebanyak 93,7 persen remaja SMP dan SMA pernah berciuman serta bercumbu berat dan oral seks. Selain itu sebanyak 62,7 persen remaja SMP mengaku sudah tidak perawan lagi. Bahkan, 21,2 persen remaja SMA mengaku pernah melakukan aborsi (Hasanuddin, 2021). Berdasarkan data tersebut dapat 
Jurnal Ilmu Komunikasi UHO : Jurnal Penelitian Kajian Ilmu Komunikasi dan Informasi.

Volume 7, No. 1, Januari 2022, hlm 92-106

dikatakan bahwa anak yang sedang memasuki masa remaja di Indonesia sangat rentan akan hal-hal yang membahayakan karena rasa ingin tahu yang tinggi tanpa adanya pengawasan, arahan dan bimbingan dari orang tua.

Di Indonesia selama masa pandemi Covid 19, banyak sektor yang terdampak baik dari sektor ekonomi hingga pendidikan. Pandemi Covid 19 merupakan sebuah kasus yang diakibatkan karena adanya penyebaran virus corona atau yang dikenal dengan COVID19 (Corona Virus Desease-2019) yang berasal dari China dengan kecepatan penyebaran yang tinggi. Berdasarkan data WHO diperoleh bahwa COVID-19 telah menjadi pandemi global dengan 4.534.0731 kasus positif yang terkonfirmasi di 216 negara di seluruh dunia (Update: 17-05-2020). Virus Corona juga telah mewabah di Indonesia sejak awal Maret hingga 12 Mei 2020 terdapat 17.514 kasus positif terkonfimasi tersebar di 34 provinsi dan 415 kabupaten/kota (Gugus Tugas Percepatan Penanganan COVID-19 Indonesia, 2020) menurut Herliandry et al. (2020) Sejak dinyatakan sebagi pandemi global, adanya penyebaran virus corona menjadikan pemerintah Indonesia pada awal bulan Maret 2020 telah mengeluarkan kebijakan mengenai pembatasan kegiatan diluar rumah, dan banyak sektor yang dialihkan menjadi bekerja dari rumah (work from home). Selain pada sektor ekonomi berupa pengalihan pekerjaan yang dilakukan dari rumah, sector pendidikan juga ikut terdampak ,akibatnya seluruh sekolah ditutup dan kegiatan belajar mengajar dilakukan secara daring atau online tanpa batas waktu yang belum ditentukan.

Berdasarkan paparan yang disampaikan oleh Susilowati selaku dosen Universitas Padjajaran melalui webinar, dengan adanya perubahan kehidupan masyarakat yang dapat menjadi permasalahan baru harus dihadapi dan tentunya berdampak bagi psikologis maupun material masyarakat. Pandemi memberikan banyak dampak bagi masyarakat, seperti masyarakat yang harus kehilangan pekerjaan dan harus memikirkan untuk mendapatkan pekerjaan lagi demi keberlangsungan hidup keluarganya. Karena kesibukan orang tua, menjadikan anak remaja yang juga harus melakukan kegiatan belajar mengajar dari rumah tentu merasa memiliki keleluasaan dalam bergaul di lingkungan sekitarnya dengan pengawasan orang tua yang lemah. Akibatnya banyak anak yang terjerumus pada pergaulan bebas hingga banyak anak remaja yang memutuskan untuk melakukan pernikahan dini dengan berbagai faktor seperti hamil diluar nikah, merasa jenuh karena harus belajar dari rumah, dan dengan alasan untuk memperbaiki keadaan ekonomi orang tua akibat adanya pandemi (unpad.ac.id, 2020). 
Jurnal Ilmu Komunikasi UHO : Jurnal Penelitian Kajian Ilmu Komunikasi dan Informasi.

Volume 7, No. 1, Januari 2022, hlm 92-106

Menurut United Nations Children's Fund (UNICEF) menyatakan bahwa pernikahan usia dini adalah pernikahan yang dilaksanakan secara resmi atau tidak resmi yang dilakukan sebelum usia 18 tahun (Zainurrahmah et al., 2019). Pernikahan dini dapat terjadi karena banyak faktor dan tentu menimbulkan dampak biologis mapun psikologis. Kasus pernikahan dini pada saat pandemi banyak terjadi di berbagai daerah di Indonesia. Berdasarkan data yang disadur dari databoks.katadata berdasarkan sumber dari UNICEF selama masa pandemi pernikahan dini di Indonesia mengalami peningkatan. Pada Januari hingga Juni 2020 sebanyak 34.000 permohonan dispensasi pernikahan dini atau pernikahan dibawah umur 19 tahun diajukan, sebanyak $97 \%$ diantaranya dikabulkan. Padahal permohonan dispensasi pernikahan dini sepanjang tahun 2019 tercatat hanya terdapat 23.700 permohonan. Terdapat berbagai faktor yang menyebabkan meningkatnya pernikahan dini di tengah pandemi antara lain dianggap sebagai solusi persoalan ekonomi keluarga, pengaruh nirma agama dan budaya setempat, serta minimnya edukasi mengenai pernikahan dini (Pusparisa, 2020).

Meningkatnya angka pernikahan dini selama masa pandemi juga terjadi di Kabupaten Kediri dengan angka mencapai 100 persen kenaikan dibanding dengan angka pernikahan dini pada tahun 2019. Kabupaten Kediri merupakan Kabupaten Kediri merupakan salah satu kabupaten di Provinsi Jawa Timur, yang memiliki pusat pemerintahan di Kediri. Kabupaten ini berbatasan dengan Kabupaten Jombang di utara, Kabupaten Malang di timur, Kabupaten Blitar dan Kabupaten Tulungagung di selatan, Kabupaten Madiun dan Kabupaten Ponorogo di barat, serta Kabupaten Nganjuk di barat dan utara. Menurut okezone.com permohonan dispensasi pernikahan atau menikah di usia dini di Kabupaten Kediri meningkat pesat selama masa pandemi Covid 19. Terhitung hingga akhir Oktober 2020, Pengadilan Agama Kabupaten Kediri telah menerima sebanyak 507 permohonan dari tahun sebelumnya yang hanya sebanyak 253 permohonan.

Berdasarkan data dari Jawa Pos Radar Kediri, meningkatnya angka pernikahan dini di Kabupaten Kediri tentu tidak terjadi pada masa pandemi saja, hal ini juga pernah terjadi pada tahun 2015 dimana sebanyak 192 pemohon dispenasasi nikah yang dilakukan pasangan muda. Sedangkan pada tahun 2016 angka tersebut turun menjadi 153 pemohon. Pengajuan disepensasi tersebut menurut Humas Pengadilan Agama Kabupaten Kediri sebanyak 85 persen diakibatkan karena mengalami kehamilan sebelum menikah (Nugroho, 2020). Angka pernikahan dini di Kabupaten Kediri tidak selalu mengalami kenaikan, namun juga mengalami penurunan. Dengan terjadinya kenaikan 100 persen yang terjadi selama masa pandemi, tentu menjadi perhatian lebih bagi masyarakat maupun pemerintah. Terjadinya 
Jurnal Ilmu Komunikasi UHO : Jurnal Penelitian Kajian Ilmu Komunikasi dan Informasi.

Volume 7, No. 1, Januari 2022, hlm 92-106

kasus pernikahan dini di Kabupaten Kediri disebabkan berbagai hal seperti hamil diluar nikah. Selain itu meskipun dengan usia yang masih remaja, pilihan untuk melakukan pernikahan dini menjadi solusi yang diambil orang tua untuk mengantisipasi perzinahan. Orang tua mengkhawatirkan anak remajanya melakukan hubungan pacaran yang kelewat batas (Arif, 2020).

Dengan meningkatnya angka dan kasus pernikahan dini pada masa pandemi tentu menjadikan sebuah permasalahan bagi orang tua ataupun pemerintah. Menurut Munasik selaku Humas Pengadilan Agama Kabupaten Kediri yang mengatakan kepada pihak bacaini.id, pandemi yang mengharuskan anak menggunakan ponsel untuk mengakses kegiatan belajar mengajar secara daring, mengakibatkan anak akan sering menggunakan ponsel setiap hari. Menurut Munasik pemicu meningkatnya pernikahan dini diakibatkan penggunaan ponsel tanpa arahan dan perhatian orang tua, sehingga anak dapat mengakses bahkan melihat film porno. Oleh sebab itu, akibat melihat film porno menjadikan anak penasaran dan akhirnya melakukan hubungan dewasa dengan lawan jenis, dalam hal ini yaitu dengan kekasihnya (Redaksi, 2020).

Berdasarkan penelitian terdahulu yang digunakan sebagai referensi peneliti yaitu Sholihah (2021) dengan judul Pola Komunikasi Orang Tua Dan Anak Di Desa Sukolilo Kecamatan Jabung Malang, Afdhilla \& Alamiyah (2021) dengan judul Pola Komunikasi Ibu Dengan Anak Perempuan Suku Jawa Dalam Pemilihan Pasangan Hidup (Studi Kasus Pada Desa Gempol, Kecamatan Rejoso, Kabupaten Nganjuk), dan Saifuddin \& Fanny (2015) dengan judul Pola Komunikasi Orang Tua Dengan Anak Pada Kasus Seks Pranikah (Studi Deskriptif Pola Komunikasi Orang Tua Dengan Anak Pada Kasus Seks Pranikah Di Surabaya), terdapat perbedaan dengan penelitian yang akan dilakukan oleh peneliti. Perbedaan tersebut yaitu meskipun penelitian terdahulu memiliki kesamaan melakukan penelitian mengenai pola komunikasi orang tua dengan anak, namun memiliki perbedaan pada objek dan lokasi penelitian. Penelitian yang akan dilakukan oleh peneliti membahas mengenai pola komunikasi orang tua dan remaja yang melakukan pernikahan dini saat pandemi di Kabupaten Kediri

Berdasarkan permasalahan diatas, tujuan dari penelitian ini yaitu untuk membahas lebih jauh mengenai bagaimana pola komunikasi antara orang tua dengan anak remaja yang memutuskan untuk melakukan pernikahan dini saat pandemic. 
Jurnal Ilmu Komunikasi UHO : Jurnal Penelitian Kajian Ilmu Komunikasi dan Informasi.

Volume 7, No. 1, Januari 2022, hlm 92-106

\section{METODE PENELITIAN}

Penelitian ini menggunakan metode penelitian kualitatif deskriptif. Penelitian kualitatif merupakan prosedur penelitian yang mampu menghasilkan data deskriptif berupa ucapan, tulisan, dan perilaku dari orang-orang yang diamati. Tujuan dari penelitian kualitatif yaitu untuk mengetahui bagaimana kondisi suatu konteks dengan mengarahkan pada pendeskripsian secara rinci dan mendalam mengenai potret kondisi dalam suatu konteks yang alami (natural setting), sesuai dengan apa yang terjadi di lapangan menurut Bogdan dan Taylor (1992) dalam Nugrahani (2014) menyatakan bahwa metode deskriptif kualitatif merupakan suatu metode yang mengunakan kata-kata, kalimat atau gambar yang memiliki arti lebih bermakna dan mampu memicu timbulnya pemahaman yang lebih nyata dari pada sekedar sajian angka atau frekuensi. Penelitian deskriptif kualitatif ditujukan untuk mendeskripsikan dan menggambarkan fenomena-fenomena yang ada, baik bersifat alamiah maupun rekayasa manusia, yang lebih memperhatikan mengenai karakteristik, kualitas keterkaitan antar kegiatan (Sukmadinata, 2016).

Dalam penelitian ini, peneliti menggunakan purposive sampling dalam menentukan informan. Purposive sampling merupakan teknik yang digunakan untuk menentukan informan berdasarkan kriteria tertentu sesuai dengan kebutuhan penelitian. Adapun kriteria informan dalam penelitian ini, antara lain : 1. Orang tua yang memiliki anak usia remaja yaitu 10-19 tahun dan melakukan pernikahan dini pada masa pandemi Covid 19, 2. Anak remaja yang berusia 10-19 tahun dan melakukan pernikahan dini selama pandemi Covid 19, dan 3. Berdomisili di Kabupaten Kediri. Penelitian ini menggunakan 6 informan sebagai sumber data, yaitu 3 orang tua yang memiliki anak remaja yang melakukan pernikahan dini saat pandemi Covid 19, dan 3 anak remaja yang melakukan pernikahan dini saat pandemi Covid 19.

Sumber data penelitian ini yaitu sumber data primer yang didapatkan secara langsung oleh peneliti dari subyek yang memiliki keterkaitan dengan penelitian, sedangkan sumber data sekunder diperoleh dari sumber data orang lain sebagai referensi berupa artikel berita, artikel jurnal, skripsi, dan juga buku. Teknik pengumpulan data dilakukan dengan wawancara mendalam dan studi literatur. Teknik analisis data yang digunakan yaitu analisis data kualitatif metode interaktif, berdasarkan pendapat Matthew B. Miles dan A. Michael Huberman (Soegiyono, 2006 dalam Hatuwe, 2013) yaitu reduksi data, penyajian data, serta penarikan kesimpulan. 
Jurnal Ilmu Komunikasi UHO : Jurnal Penelitian Kajian Ilmu Komunikasi dan Informasi.

Volume 7, No. 1, Januari 2022, hlm 92-106

\section{HASIL DAN PEMBAHASAN}

Berdasarkan hasil pengumpulan data melalui wawancara yang dilakukan oleh peneliti, diperoleh data berupa informasi dan pengalaman informan diantaranya SW (50tahun) orang tua dari AC (15tahun), S (55 tahun) orang tua dari DW (18 tahun), dan T (47 tahun) orang tua dari M (18 tahun). Dalam proses analisis, peneliti mengkaitkan hasil wawancara dengan teori yang ada untuk menjawab rumusan masalah penelitian. Setelah itu, hasil wawancara akan dikelompokkan menjadi beberapa kategori yang berkaitan dengan pola komunikasi orang tua dengan anak serta teori atribusi. Tujuan dikelompokkannya hasil wawancara yaitu untuk mengetahui dan menjelaskan keterkaitan pola komunikasi yang diterapkan orang tua kepada anak atas keputusan pernikahan dini yang terjadi.

Hasil wawancara dengan informan SW dan AC menunjukkan bahwa pola komunikasi yang diterapkan yaitu pola komunikasi permissive (membebaskan), hal tersebut terlihat dari bagaimana SW memberikan kebebasan kepada AC dalam melakukan kegiatan sehari-hari. Namun, dikarenakan SW harus bekerja sehingga tidak bisa mengontrol AC setiap waktu. Menurut AC, dikarenakan ia merasa dibebaskan dan ia masih memiliki rasa ingin tahu yang tinggi, namun tidak terlalu banyak bercerita mengenai kehidupan pribadinya menjadikan AC melakukan hal diluar pengawasan SW selaku orang tua. Hal itulah yang menjadikan AC saat pandemi merasa kegiatannya lebih bebas sehingga masuk kedalam pergaulan bebas hingga melakukan kegiatan yang menyimpang, dan menjadikan AC mengalami kehamilan diluar nikah. Penyebab SW memperbolehkan AC melakukan pernikahan dini dikarenakan ia merasa bahwa pasangan AC yang juga masih berumur 15 tahun harus bertanggung jawab atas tindakannya, supaya tidak terlalu mendapatkan sanksi sosial di masyarakat.

Pola komunikasi yang diterapkan oleh keluarga SW merupakan pola komunikasi permissive (membebaskan) menurut (Yusuf, 2001:51 dalam Sholihah, 2021) yaitu pola yang sikap penerimaan orang tua tinggi, namun kontrolnya rendah dan memberi kebebasan kepada anak untuk menyatakan dorongan atau keinginan. Hal tersebut tentu sesuai dengan pola komunikasi yang diterapkan SW kepada AC yaitu memberikan kebebasan dalam berkegiatan namun tidak mampu mengawasi kegiatannya. Keterkaitan dengan teori atribusi yang menjelasakan bahwa proses bagaimana menentukan penyebab dan motif tentang perilaku seseorang. Teori ini mengacu tentang pemahaman akan reaksi seseorang terhadap peristiwa di sekitar mereka, dengan mengetahui alasan - alasan mereka atas kejadian yang dialami. Dalam hal ini SW dengan kesibukannya bekerja menerapkan sikap penerimaan yang tinggi namun control terhadap kegiatan AC yang rendah, sehingga menjadikan AC merasa 
Jurnal Ilmu Komunikasi UHO : Jurnal Penelitian Kajian Ilmu Komunikasi dan Informasi.

Volume 7, No. 1, Januari 2022, hlm 92-106

bebas untuk melakukan kegiatan diluar rumah tanpa pengawasan orang tua. Karena kebebasan yang tidak terkontrol menjadikan AC melakukan kegiatan yang menyimpang hingga menjadikan AC mengalami kehamilan diluar nikah dan akhirnya harus melakukan pernikahan dini.

Pada keluarga S (55 tahun) pola komunikasi yang diterapkan kepada DW ( 18 tahun) yaitu pola komunikasi permissive (membebaskan) dikarenakan S memberikan kepercayaan kepada DW untuk melakukan kegiatan sehari-hari. Hal tersebut dilakukan S dikarenakan ia harus bekerja sehingga kurang dalam berkomunikasi dengan DW. Selain itu S juga memberikan kebebasan DW untuk memilih keputusannya sendiri, hal tersebut terlihat ketika DW memutuskan untuk tidak melanjutkan pendidikannya pada jenjang Sekolah Menengah Atas (SMA). Alasan S mengijinkan DW unutk melakukan pernikahan dini yaitu dikarenakan S merasa bahwa DW telah mendapatkan pasangan dengan umur yang lebih dewasa, sehingga ia merasa bahwa DW akan lebih mandiri. Selain itu, S merasa bahwa DW yang sudah memutuskan untuk tidak melanjutkan pendidikannya dan sudah mendapatkan pekerjaan akan mampu menjalani pernikahan yang diputuskan oleh dirinya sendiri tanpa paksaan orang tua. Alasan S memutuskan untuk melakukan pernikahan dini saat pandemi dikarenakan ia merasa bahwa sudah menemukan pasangan yang perhatian dan menjadi tempat yang nyaman unutk diajak bercerita, dan ingin melakukan pernikahan dini tanpa memikirkan keadaan.

Pola komunikasi yang diterapkan oleh keluarga S merupakan pola komunikasi permissive (membebaskan) menurut (Yusuf, 2001 dalam Sholihah, 2021) yaitu pola yang sikap penerimaan orang tua tinggi, namun kontrolnya rendah dan memberi kebebasan kepada anak untuk menyatakan dorongan atau keinginan. Hal tersebut tentu sesuai dengan pola komunikasi yang diterapkan S kepada DW yaitu memberikan kebebasan dalam berkegiatan namun control terhadap kegiatannya rendah. Hal tersebut juga terlihat ketika $S$ memberikan kebebasan DW unutk memutuskan keinginannya sendiri untuk tidak melanjutkan pendidikan ke jenjang yang lebih tinggi, serta melakukan pernikahan dini dengan pasangan pilihannya. Keterkaitan dengan teori atribusi yang menjelasakan bahwa proses bagaimana menentukan penyebab dan motif tentang perilaku seseorang. Teori ini mengacu tentang pemahaman akan reaksi seseorang terhadap peristiwa di sekitar mereka, dengan mengetahui alasan - alasan mereka atas kejadian yang dialami. Dalam hal ini $\mathrm{S}$ dengan kesibukannya bekerja menerapkan sikap penerimaan yang tinggi namun kontrol terhadap kegiatan DW rendah, sehingga menjadikan DW merasa bebas untuk melakukan kegiatan diluar rumah serta merasa diberikan kebebasan untuk memutuskan pilihannya 
Jurnal Ilmu Komunikasi UHO : Jurnal Penelitian Kajian Ilmu Komunikasi dan Informasi.

Volume 7, No. 1, Januari 2022, hlm 92-106

sendiri. Karena kurangnya komunikasi antara S dengan DW dalam kehidupan sehari-hari akibat kesibukan masing-masing, menjadikan DW berusaha menemukan pasangan yang membuatnya merasa nyaman untuk berkomunikasi. Karena hal itulah yang menjadikan DW melakukan pernikahan dini saat pandemi dan S mengijinkan tanpa memikirkan keadaan.

Penerapan pola komunikasi oleh keluarga T (47 tahun) pada M ( 18 tahun) yaitu pola komunikasi authoritarian (otoriter), hal tersebut dapat terlihat dari bagaimana $\mathrm{T}$ memperlakukan M dengan memberikan batasan jam keluar malam yaitu pukul 9 malam harus sudah berada di rumah, apabila melanggar terkadang $M$ juga mendapat hukuman berupa omelan dan tidak diperbolehkan keluar rumah selama beberapa hari selain bekerja. Selain itu dikarenakan M yang memutuskan untuk tidak melanjutkan pendidikan ke jenjang Sekolah Menengah Atas (SMA) menjadikan M telah bekerja pada sebuah rumah makan. Meskipun M sudah bekerja, $\mathrm{T}$ sebagai orang tua tetap mengawasi kegiatan $\mathrm{M}, \mathrm{T}$ tetap menanyakan keberadaan M pada majikannya. Alasan $\mathrm{T}$ melakukan hal tersebut dikarenakan, ia tidak memperbolehkan M memiliki hubungan pacaran. T takut apabila M melakukan kebohongan dengan ijin bohong akan kegiatannya. M merasa bahwa ia merasa terkekang dengan aturan yang dibuat oleh $\mathrm{T}$ perihal kegiatannya, bahkan $\mathrm{M}$ juga pernah berbohong kepada $\mathrm{T}$ supaya diperbolehkan untuk keluar bersama temannya. Alasan T memperbolehkan M melakukan pernikahan dini dikarenakan $\mathrm{M}$ dijodohkan oleh anak dari pemilik rumah makan tempat $\mathrm{M}$ bekerja. $\mathrm{T}$ merasa bahwa anak majikan $\mathrm{M}$ akan mampu menjaga $\mathrm{M}$ dengan melakukan pernikahan, daripada harus berpacaran yang menjadikan terjadinya hal-hal yang menyimpang. Dengan keputusan tersebut, $M$ sebagai anak yang penurut tentu menyetujui keputusan $\mathrm{T}$ sebagai orang tuanya

Pola komunikasi yang diterapkan oleh keluarga $\mathrm{T}$ merupakan pola komunikasi authoritarian (otoriter) menurut (Yusuf, 2001 dalam Sholihah, 2021) yaitu pola dimana sikap penerimaan (acceptance) orang tua rendah, namun kontrol tinggi, suka menghukum secara fisik, bersikap mengkomando, bersikap kaku (keras), cendrung emosional dan bersikap menolak. Hal tersebut tentu sesuai dengan pola komunikasi yang diterapkan $\mathrm{T}$ kepada $\mathrm{M}$ yaitu $\mathrm{T}$ memberikan batasan serta mengkontrol kegiatan $\mathrm{M}$, namun tidak mau menerima keinginan M. Apabila M melanggar aturan yang dubuat $\mathrm{T}$ juga mendapatkan hukuman. Sehingga $M$ selalu mengikuti keputusan yang dibuat oleh $\mathrm{T}$ sebagai orang tuanya. Hal tersebut dapat terlihat ketika M selalu diawasi setiap kegiatannya dan melakukan pernikahan dini karena perjodohan atas keputusan T. Keterkaitan dengan teori atribusi yang menjelasakan bahwa proses bagaimana menentukan penyebab dan motif tentang perilaku 
Jurnal Ilmu Komunikasi UHO : Jurnal Penelitian Kajian Ilmu Komunikasi dan Informasi.

Volume 7, No. 1, Januari 2022, hlm 92-106

seseorang. Teori ini mengacu tentang pemahaman akan reaksi seseorang terhadap peristiwa di sekitar mereka, dengan mengetahui alasan - alasan mereka atas kejadian yang dialami. Dalam hal ini $\mathrm{T}$ dengan segala keputusan yang harus ditaati oleh $\mathrm{M}$ menerapkan sikap penerimaan yang rendah namun control terhadap kegiatan $M$ yang tinggi. Hal itu yang menjadikan $\mathrm{M}$ melakukan perikahan dini akibat keputusan orang tuanya.

Berdasarkan hasil dan pembahasan diatas jika dibandingan dengan peneltian terdahulu yang dilakukan oleh Sholihah (2021) dapat diketahui bahwa dalam penerapan pola komunikasi orang tua dengan anak untuk meningkatkan nilai-nilai kepatuhan dalam keluarga ditemukan bahwa pola komunikasi yang diterapkan yaitu authoritarian (otoriter), permissive (membebaskan), serta authoritative (demokrasi). Pada penelitian yang dilakukan oleh Afdhilla \& Alamiyah (2021) dapat diketahui bahwa dalam penerapan pola komunikasi ibu dengan anak dalam pemilihan pasangan hidup yaitu authoritarian (otoriter), authoritative (demokrasi). Sedangkan pada penelitian ini hanya ditemukan pola komunikasi yang terjadi antara orang tua dengan remaja yang melakukan pernikahan dini saat pandemi yaitu authoritarian (otoriter) dan permissive (membebaskan). Selain itu, pada penelitian yang dilakukan oleh Afdhilla \& Alamiyah (2021) bahwa dalam menganalisis data menggunakan teori dialogis hubungan. Sedangkan pada penelitian ini menggunakan teori atribusi yang membantu untuk menganalsis data. Sedangkan pada penelitian Saifuddin \& Fanny (2015), Sholihah (2021), serta Afdhilla \& Alamiyah (2021) memiliki perbedaan dengan penelitian ini yaitu terdapat pada perbedaan objek dan lokasi penelitian.

\section{SIMPULAN}

Berdasarkan hasil penelitian yang dilakukan peneliti mengenai pola komunikasi orang tua dengan remaja yang melakukan pernikahan dini saar pandemi di Kabupaten Kediri, masing-masing keluarga menerapkan pola komunikasi yang berbeda-beda. Hal tersebut dapat terlihat ketika informan menerapkan pola komunikasi authoritarian ( otoriter) dan permissive (membebaskan) kepada anak remajanya. Pola komunikasi authoritarian (otoriter) cenderung tidak menerima pendapat atau keinginan anak, dan kontrol terhadap kegiatan anak tinggi. Sedangkan pola komunikasi permissive (membebaskan) cenderung lebih menerima pendapat atau keinginan anak namun dengan kontrol kegiatan yang rendah.

Pada hasil wawancara yang dilakukan oleh 6 informan dengan 3 orang tua serta 3 anak remaja ditemukan penerapan pola komunikasi authoritarian (otoriter) terjadi pada anak 
Jurnal Ilmu Komunikasi UHO : Jurnal Penelitian Kajian Ilmu Komunikasi dan Informasi.

Volume 7, No. 1, Januari 2022, hlm 92-106

remaja yang melakukan pernikahan dini akibat perjodohan yang dilakukan oleh orang tuanya. Sedangkan pada penerapan pola komunikasi permissive (membebaskan) terjadi pada pernikahan dini yang dilakukan anak remaja yang disebabkan kehamilan diluar nikah akibat kurangnya pengawasan orang tua serta anak yang tidak melanjutkan pendidikan ke jenjang yang lebih tinggi sehingga memutuskan untuk melakukan pernikahan dini akibat keinginan dan keputusan dirinya sendiri. 
Jurnal Ilmu Komunikasi UHO : Jurnal Penelitian Kajian Ilmu Komunikasi dan Informasi.

Volume 7, No. 1, Januari 2022, hlm 92-106

\section{DAFTAR PUSTAKA}

Afdhilla, A. B., \& Alamiyah, S. S. (2021). Pola Komunikasi Ibu dengan Anak Perempuan Suku Jawa dalam Pemilihan Pasangan Hidup (Studi Kasus pada Desa Gempol,

Kecamatan Rejoso, Kabupaten Nganjuk). Syntax Literate: Jurnal Ilmiah Indonesia, $6(4)$.

Arif, S. (2020). Banyak Pasangan Nikah Dini di Masa Pandemi.

Debby, Sururuddin, \& Maulana. (2021). Pola Komunikasi Orang Tua Dengan Remaja Terhadap Penggunaan Facebook Di Desa Sungai Aur Kecamatan Kumpeh Kabupaten Muaro Jambi.

Hasanuddin. (2021). Survei Kpai Menggambarkan Perilaku Seks Bebas Kalangan Remaja Di Indonesia. Warta Kota 1 Januari 2021.

Hatuwe. (2013). Pola Komunikasi Keluarga Dalam Mencegah Kenakalan Remaja. E-Journal Ilmu Komunikasi, 1(4), 200-209.

Herliandry, Nurhasanah, Suban, \& Kuswanto. (2020). Pembelajaran Pada Masa Pandemi Covid-19. JTP-Jurnal Teknologi Pendidikan, 22(1), 65-70.

Kartini. (2017). Pola Komunikasi Pasangan Pernikahan Usia Dini Di Desa Gegarang Kecamatan Blangjerango Kabupaten Gayo Lues.

Latif. (2019). Pola Komunikasi Keluarga Dalam Pengambilan Keputusan Perkawinan Usia Remaja (Studi Di Desa Lempuh Kecamatan Blangkejeren Kabupaten Gayo Lues.

Novianti, Sondakh, \& Rembang. (2017). Komunikasi Antarpribadi Dalam Menciptakan

Harmonisasi (Suami Dan Istri) Keluarga Didesa Sagea Kabupaten Halmahera Tengah. Acta Diurna Komunikasi, 6(2).

Nugrahani, F. (2014). Metode Penelitia Kualitatif. Cakra Books.

Nugroho, A. (2020). Ratusan Pasangan Nekat Menikah Mudah. Radarkediri.Jawapos.Com. https://radarkediri.jawapos.com/politik/28/12/2020/ratusan-pasangan-nekat-menikahmuda

Pusparisa. (2020). Jutaan Anak Perempuan di Indonesia Lakukan Pernikahan Dini. Databoks.Katadata.Co.Id.

Redaksi. (2020). Penggunaan Ponsel Picu Pernikahan Dini di Kediri. Bacaini.Id.

Saifuddin, \& Fanny. (2015). Pola Komunikasi Orang Tua Dengan Anak Pada Kasus Seks Pranikah (Studi Deskriptif Pola Komunikasi Orang Tua Dengan Anak Pada Kasus Seks 
Jurnal Ilmu Komunikasi UHO : Jurnal Penelitian Kajian Ilmu Komunikasi dan Informasi.

Volume 7, No. 1, Januari 2022, hlm 92-106

Pranikah Di Surabaya). Jurnal Ilmu Komunikasi, 7(2).

Sari. (2017). Komunikasi Antarpribadi. Deepublish.

Sholihah. (2021). Pola Komunikasi Orang Tua Dan Anak Di Desa Sukolilo Kecamatan Jabung Malang. Al-Ittishol: Jurnal Komunikasi Dan Penyiaran Islam, 2(2), 97-109.

Sukmadinata, N. S. (2016). Metode Penelitian Pendidikan. Remaja Rosda Karya.

unpad.ac.id. (2020). Pernikahan Dini di Indonesia Meningkat selama Pandemi. Unpad.Ac.Id. Zainurrahmah, Meilani, \& Kurniati. (2019). Faktor-Faktor Yang Berhubungan Dengan Pernikahan Dini Di Kecamatan Playen Kabupaten Gunungkidul Tahun 2018. 